\title{
Exercise-induced oxidative stress in older adults as measured by antipyrine oxidation
}

Citation for published version (APA):

Meijer, E. P., Coolen, S. A. J., Bast, A., \& Westerterp, K. R. (2001). Exercise-induced oxidative stress in older adults as measured by antipyrine oxidation. Metabolism-Clinical and Experimental, 50(12), 14841488. https://doi.org/10.1053/meta.2001.28086

Document status and date:

Published: 01/01/2001

DOI:

10.1053/meta.2001.28086

Document Version:

Publisher's PDF, also known as Version of record

Document license:

Taverne

Please check the document version of this publication:

- A submitted manuscript is the version of the article upon submission and before peer-review. There can be important differences between the submitted version and the official published version of record.

People interested in the research are advised to contact the author for the final version of the publication, or visit the DOI to the publisher's website.

- The final author version and the galley proof are versions of the publication after peer review.

- The final published version features the final layout of the paper including the volume, issue and page numbers.

Link to publication

\footnotetext{
General rights rights.

- You may freely distribute the URL identifying the publication in the public portal. please follow below link for the End User Agreement:

www.umlib.nl/taverne-license

Take down policy

If you believe that this document breaches copyright please contact us at:

repository@maastrichtuniversity.nl

providing details and we will investigate your claim.
}

Copyright and moral rights for the publications made accessible in the public portal are retained by the authors and/or other copyright owners and it is a condition of accessing publications that users recognise and abide by the legal requirements associated with these

- Users may download and print one copy of any publication from the public portal for the purpose of private study or research.

- You may not further distribute the material or use it for any profit-making activity or commercial gain

If the publication is distributed under the terms of Article $25 \mathrm{fa}$ of the Dutch Copyright Act, indicated by the "Taverne" license above, 


\title{
Exercise-Induced Oxidative Stress in Older Adults as Measured by Antipyrine Oxidation
}

\author{
Erwin P. Meijer, Stefan A.J. Coolen, Aalt Bast, and Klaas R. Westerterp
}

\begin{abstract}
Aging is associated with increased susceptibility to free radical-mediated tissue damage. Measuring exercise-induced oxidative stress, however, is a major problem in free radical research. We used an exogenous marker (antipyrine) to measure oxidative stress in older adults during submaximal exercise. Antipyrine pharmacokinetics is independent of blood flow to the liver. Furthermore, antipyrine reacts quickly with hydroxyl radicals $\left(10^{10}-10^{11} \mathrm{~L} \cdot \mathrm{mol}^{-1} \cdot \mathrm{s}^{-1}\right)$ to form para- and orthohydroxyantipyrine (o-APOH). o-APOH is not formed in man through the mono-oxygenase pathway of cytochrome P450. Thirty-four subjects (62 \pm 1 years) orally ingested $10 \mathrm{mg}$ antipyrine/kg body mass. One hour after ingestion subjects cycled 45 minutes at $\mathbf{5 0 \%}$ maximal power output. Exercise significantly increased the ratio of para-hydroxyantipyrine (p-APOH) to native antipyrine in plasma $(.0014 \pm .0001 \mathrm{v} .0021 \pm .0002 ; P<.0001)$. Also, the ratio of o-APOH was significantly increased after exercise $(.0014 \pm .0001 v .0019 \pm .0002 ; P<.0001)$. Exercise significantly increased plasma levels of plasma malondialdehyde MDA) $(.55 \pm .07 v .92 \pm .21 \mu \mathrm{mol} / \mathrm{L} ; P<.01)$. In conclusion, in older adults, oxidative stress occurs during cycling at submaximal intensity as measured with free radical reaction products of antipyrine.

Copyright $\odot 2001$ by W.B. Saunders Company
\end{abstract}

$\mathbf{P}$ HYSICAL EXERCISE markedly increases oxygen uptake particularly in skeletal muscle. ${ }^{1}$ Increased oxygen consumption further increases the leaking of reactive oxygen species (ROS), such as superoxide, hydroxyl radical $\left(\mathrm{OH}^{\circ}\right)$, and singlet oxygen, as products of oxidative phosphorylation, from the mitochondrial electron transport chain. ${ }^{2}$ The imbalance, in favor of the free radicals, between the increased ROS generation and the scavenging capacity is termed oxidative stress.

Aging is associated with an increased susceptibility to free radical-mediated tissue damage. ${ }^{3-5}$ Monitoring the amount of oxidative stress in vivo, however, is a major problem in free radical research. ${ }^{6}$ Most human studies investigating exerciseinduced oxidative stress have relied on indirect endogenous indices of free radical damage, such as plasma malondialdehyde (MDA) levels, ${ }^{7}$ conjugated dienes,${ }^{8}$ and serum lipid peroxides. ${ }^{9}$ Although these studies showed an increase in postexercise lipid peroxidation, the major disadvantage of using endogenous markers in vivo is the possibility that they are not only formed by free radicals, but also by other pathways, for example, MDA could be formed by the enzymatic breakdown of prostaglandin endoperoxides. ${ }^{6}$ A suitable approach to measure oxidative stress directly in vivo is aromatic hydroxylation by salicylic acid ${ }^{10,11}$ or phenylalanine. ${ }^{12,13}$ These methods are based on the ability of $\mathrm{OH}^{-}$to attack the benzene rings of aromatic molecules and to produce hydroxylated compounds that can be measured directly. Salicylic acid, however, has a high biologic half-life of about 15 to 20 minutes, and the metabolic breakdown depends on blood flow to the liver, which are disadvantages during endurance exercise experiments. ${ }^{14}$

This study used antipyrine (2,3-dimethyl-1-phenyl-3-pyrazo-

From the Nutrition and Toxicology Research Institute Maastricht NUTRIM, Departments of Human Biology Pharmacology and Toxicology, Maastricht University, Maastricht, The Netherlands.

Submitted February 9, 2001; accepted May 21, 2001.

Address reprint requests to Erwin P. Meijer, PhD, Department of Human Biology, Maastricht University, PO Box 616, 6200 MD Maastricht, The Netherlands.

Copyright $\odot 2001$ by W.B. Saunders Company

0026-0495/01/5012-0008\$35.00/0

doi:10.1053/meta.2001.28086 line-5-one) as an aromatic probe for assessing oxidative stress. The properties of antipyrine make it a very suitable marker. Following oral ingestion, antipyrine is uniformly distributed in the total body water after approximately 1 hour. ${ }^{15}$ Antipyrine breakdown is independent of blood flow to the liver, which is important during exercise where blood flow is altered. Due to the reactive phenyl group, the reaction rate constant with $\mathrm{OH}^{-}$ is in the order of $10^{10}-10^{11} \mathrm{~L} \cdot \mathrm{mol}^{-1} \cdot \mathrm{s}^{-1} \cdot{ }^{16}$ Exposure of an antipyrine solution in water to ${ }^{60} \mathrm{Co} \gamma$-radiation leads to the formation of 3 phenolic antipyrine derivatives: para-hydroxyantipyrine (p-APOH), ortho-hydroxyantipyrine (o-APOH), and meta-hydroxyantipyrine (m-APOH). The last 2 metabolites are not endogenously formed. ${ }^{17}$ The ratio of the hydroxylated products of antipyrine and the plasma concentration of antipyrine reflects the oxidative stress in vivo.

Although older people may be more susceptible to oxidative stress, so far studies have only measured exercise-induced oxidative stress in older adults by using endogenous markers. Therefore, the purpose of this study was to examine the effect of submaximal exercise on oxidative stress in older adults by using free radical reaction products of antipyrine.

\section{MATERIALS AND METHODS}

\section{Design}

In this study, 34 older subjects ( $62 \pm 1$ years) subjects performed a maximal exercise test and at least 2 hours thereafter a 45 -minute cycling test at submaximal intensity. Exercise-induced oxidative stress was measured before and after the 45 -minute cycling test by using free radical reaction products of antipyrine.

\section{Subjects}

The subjects were recruited from advertisements in the local media. Selection criteria were age over 55 years, no health problems, and no participation in regular sports activities or exercise programs during the previous year. Physical characteristics of the subjects are shown in Table 1. Detailed information concerning the purpose and methods used in the study was provided, and written consent was obtained. The local Ethical Committee approved the study.

\section{Protocol}

After an overnight stay in the laboratory, subjects first performed a maximal exercise test (7:30 AM) of about 10 to 15 minutes. Maximal 
Table 1. Subject Characteristics (means \pm SEM)

\begin{tabular}{lc}
\hline No. (men/women) & $21 / 13$ \\
Age $(\mathrm{yr})$ & $62 \pm 1$ \\
Body mass $(\mathrm{kg})$ & $75.1 \pm 2.4$ \\
Height $(\mathrm{m})$ & $1.71 \pm 0.2$ \\
$\mathrm{BMI}\left(\mathrm{kg} \cdot \mathrm{m}^{-2}\right)$ & $26 \pm 1$ \\
Fat mass $(\%)$ & $32 \pm 2$ \\
$\mathrm{VO}_{2 \max }\left(\mathrm{L} \cdot \mathrm{min}^{-1}\right)$ & $1.98 \pm 0.09$ \\
$\mathrm{~W}_{\max }(\mathrm{W})$ & $130 \pm 7$ \\
$50 \% \mathrm{~W}_{\max }(\mathrm{W})$ & $65 \pm 3$ \\
\hline
\end{tabular}

NOTE. Percent fat mass was determined by using deuterium dilution combined with a measurement of underwater weighing.

Abbreviation: BMI, body mass index.

power output $\left(\mathrm{W}_{\max }\right)$ and maximal $\mathrm{O}_{2}$ consumption $\left(\dot{\mathrm{VO}}_{2 \max }\right)$ were determined on an electromagnetically braked cycle ergometer (Lode Excalibur, Groningen, The Netherlands), as described previously. ${ }^{18}$ During the test, $\mathrm{O}_{2}$ uptake was measured continuously using a computerized open system (SensorMedics 2900 analyzer, Anaheim, CA). Additionally, heart rate was measured continuously (Polar Sport Tester, Kempele, Finland). At least 1 hour after the exercise test, a Teflon catheter (Baxter Quick Cath II, Swinford, Ireland) was inserted into an antecubital vein, and a resting blood sample $(10 \mathrm{~mL})$ was drawn. After that (9:00 AM), subjects orally ingested $10 \mathrm{mg}$ antipyrine (Janssen, Geel, Belgium) per kilogram body mass. One hour after ingestion (10:00 AM), they started to cycle for 45 minutes at $50 \% \mathrm{~W}_{\max }$. Blood samples were drawn before the exercise protocol, 20 minutes during the exercise protocol, and immediately after exercise. Blood was collected into EDTA (1.34 mmol/L) and glutathione (GSH, $0.65 \mathrm{mmol} / \mathrm{L})$ containing tubes and was centrifuged immediately $(3,000 \mathrm{rpm}) 10$ minutes at $4^{\circ} \mathrm{C}$. Aliquots of plasma were frozen immediately in liquid nitrogen and stored at $-20^{\circ} \mathrm{C}$ until further analysis of MDA and of antipyrine and its phenolic derivatives.

\section{Oxidative Stress}

Antipyrine and MDA were used as markers for oxidative stress. Antipyrine and its hydroxylated metabolites were measured in plasma by reversed-phase high-performance liquid chromatography-mass spectrometry (HPLC-MS) as described previously. ${ }^{19}$ Briefly, a reversed-phase Supersphere RP18 Endcapped column (LC-Packings, Amsterdam, The Netherlands), $150 \times 1 \mathrm{~mm} \mathrm{ID,} \mathrm{d}_{\mathrm{p}}=4 \mu \mathrm{m}$ was attached to a LC system consisting of a LC-10AT pump (Shimadzu, Kyoto, Japan) and a Triathlon autosampler (Spark Holland, Emmen, The Netherlands). The HPLC was connected to an API-300 LC/ MS/MS (Perkin Elmer Sciex Instruments, Thornhill, Canada), which operated in the multiple reaction mode, and Turbo Ionspray ionization was used as interface between HPLC and MS. Sample pretreatment consisted of $\mathrm{C} 18$ solid phase extraction (Sep-Pak C18; Cartridges, Waters, MA) to wash out salts and proteins. Cartridges were conditioned with methanol and $\mathrm{H}_{2} \mathrm{O}$. After that, $450 \mu \mathrm{L}$ plasma was inserted in the cartridge, followed by $2 \mathrm{~mL}$ ammonium-acetate buffer (10 $\mathrm{mmol} / \mathrm{L}, \mathrm{pH}$ 5). The cartridge was flushed with $1.5 \mathrm{~mL}$ methanol to elute the target components. The samples were evaporated to dryness under nitrogen pressure and dissolved with $450 \mu \mathrm{L} \mathrm{H}_{2} \mathrm{O}$ after which they stayed 30 minutes in a waterbath $\left(30^{\circ} \mathrm{C}\right)$. Afterwards, treated samples were filtered by using Spartan 13/20 filters (Schleicher \& Schuell, Dassel, Germany).

Because a competitive effect exists between antipyrine and other biomolecules for reaction with $\mathrm{OH}$, the formation of the free radical reaction products of antipyrine is dependent on the available concentration of antipyrine. Therefore, ratios of phenolic derivatives to native antipyrine are used, similar to the salicyclic acid method. ${ }^{20}$
MDA was measured in plasma using a fluorescent thiobarbituric acid (TBA) assay. TBA, $0.375 \mathrm{~g}$ (Sigma-Aldrich Chemie BV, Zwijndrecht, The Netherlands) was dissolved in $250 \mathrm{~mL}^{2} \mathrm{H}_{2} \mathrm{O}$ and $2.5 \mathrm{~mL} 1 \mathrm{~mol} / \mathrm{L}$ $\mathrm{HCl}$. A total of $111 \mu \mathrm{L}$ plasma and $1,000 \mu \mathrm{L}$ TBA solution was mixed and vortexed in an Eppendorf cup, after which it was placed in a waterbath $\left(95^{\circ} \mathrm{C}\right)$ for 1 hour. Samples were cooled down to room temperature, and the absorption was measured spectrophotometrically at $532 \mathrm{~nm}$ (Spectronic 1001, Meyvis, Bergen op Zoom, The Netherlands).

\section{Statistics}

All data are means \pm SEM. Statistical analysis of the data was performed using a nonparametric Wilcoxon signed-ranked test, because the data was not normally distributed and to minimize for big interindividual differences. Statistical significance was set at $P<.05$. The StatView5.0 program (SAS Institute, Cary, NC) was used as the statistical package.

\section{RESULTS}

Forty-five minutes of cycling at a submaximal intensity significantly increased the ratio of $\mathrm{p}-\mathrm{APOH}$ to native antipyrine when compared with the ratio before exercise $(.0014 \pm .0001$ $v .0021 \pm .0002 ; P<.0001 ;$ Fig 1A). Additionally, the ratio of $\mathrm{o}-\mathrm{APOH}$ to native antipyrine was significantly increased after exercise when compared with the ratio before exercise $(.0014 \pm .0001 v .0019 \pm .0002 ; P<.0001 ;$ Fig 1B $)$. The increase in both ratios was due to an increased concentration of p-APOH and o-APOH after exercise and not to changes in antipyrine concentration $(158.5 \pm 9.8 \mu \mathrm{mol} / \mathrm{L}$ and $155.6 \pm 9.4$ $\mu \mathrm{mol} / \mathrm{L}$ before and after exercise, respectively). MDA levels in plasma were significantly increased immediately after exercise $(.55 \pm .07 v .92 \pm .21 \mu \mathrm{mol} / \mathrm{L} ; P<.01 ;$ Fig 2$)$. Also after 20 minutes of cycling, MDA levels were significantly increased when compared with pre-exercise levels $(.55 \pm .07 v .71 \pm .13$ $\mu \mathrm{mol} / \mathrm{L} ; P<.05)$.

\section{DISCUSSION}

So far, studies in older adults that examined exercise-induced oxidative stress have relied on endogenous markers. This study investigated exercise-induced oxidative stress in older adults by using antipyrine as an exogenous marker. Results showed that the ratios of phenolic derivatives to native antipyrine were significantly increased after a 45-minute exercise at a submaximal intensity. Thus, in older adults submaximal exercise increased oxidative stress, which is in accordance with previous studies that have relied on endogenous markers. ${ }^{21,22}$ Meydani et $\mathrm{al}^{22}$ observed a steady increase in the urinary TBA level after a 45-minute running down on an inclined treadmill in 55 to 74 -year-old subjects. Leaf et $\mathrm{al}^{21}$ observed a significant increase in the postexercise levels of expired ethane and pentane in 44 to 77-year-old cardiac patients. However, endogenous markers have several methodologic disadvantages. ${ }^{6}$

An appropriate approach to measure oxidative stress directly in vivo is aromatic hydroxylation by using salicylic acid ${ }^{10,11}$ or phenylalanine. ${ }^{12,13}$ A disadvantage of salicylic acid, however, is that the metabolic breakdown is dependent on blood flow to the liver, which makes it less suitable during exercise experiments where liver blood flow will be altered. Additionally, the biological half-life is about 15 to 20 minutes, resulting in a high metabolic breakdown. ${ }^{12}$ A serious disadvantage of phenylala- 

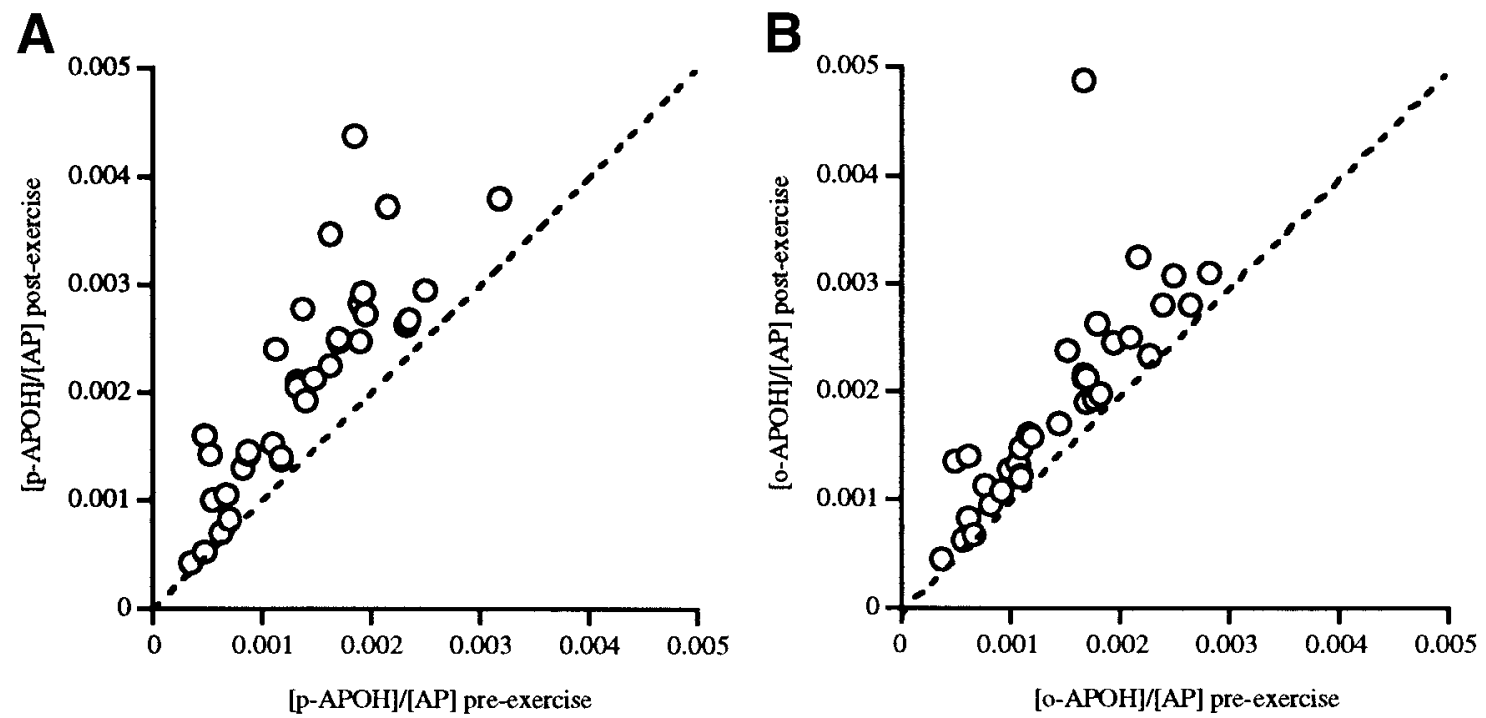

Fig 1. (A) Ratio of $\mathrm{p}$-APOH to native antipyrine (AP) in plasma of all subjects before (x-axis) and immediately after exercise ( $y$-axis). If there was no difference between the ratio before and after exercise, the line of identity (dotted line) would have been found ( $P<.0001)$. (B) Ratio of $0-A P O H$ to native AP in plasma of all subjects before (x-axis) and immediately after exercise (y-axis). If there was no difference between the ratio before and after exercise, the line of identity (dotted line) would have been found $(P<.0001)$.

nine is its relatively low rate constant for reaction with $\mathrm{OH}^{\circ}$, at $1.9^{9} \mathrm{~L} \cdot \mathrm{mol}^{-1} \cdot \mathrm{s}^{-1} .12$

The novel antipyrine method used in this study has some advantages over the existing methods. First, the reaction rate constant with $\mathrm{OH}^{\circ}$ is in the order of $10^{10}-10^{11} \mathrm{~L} \cdot \mathrm{mol}^{-1} \cdot \mathrm{s}^{-1}$, which is higher than the reaction rate of salicylic acid and phenylalanine with $\mathrm{OH}^{-}{ }^{16}$ Reaction with $\mathrm{OH}^{-}$results in the formation of 2 in plasma measurable hydroxylated metabolites,

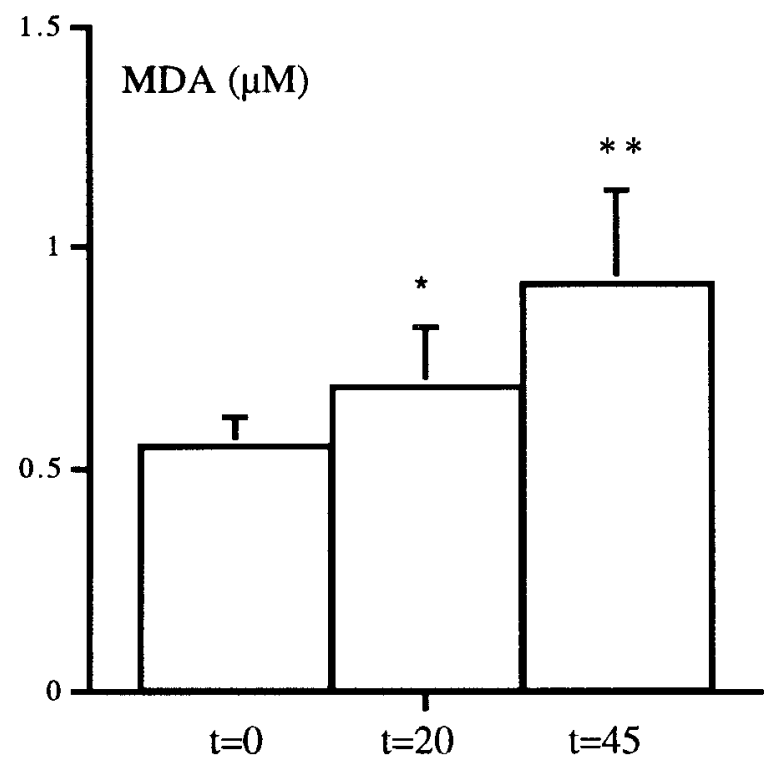

Fig 2. Plasma concentration of MDA \pm SEM $(\mu \mathrm{mol} / \mathrm{L})$, before $(t=$ $0), 20$ minutes $(t=20)$, and immediately after exercise at $50 \% \mathrm{~W}_{\max }$ $(t=45)$. Statistical difference when compared with $t=0,{ }^{*} P<.05$; $* * P<.01$. of which at least $1(\mathrm{o}-\mathrm{APOH})$ is not known to be formed by the human mono-oxygenase pathway of cytochrome P450. ${ }^{17} \mathrm{Sec}-$ ond, metabolic breakdown of antipyrine is independent on blood flow to the liver, which is important during exercise where blood flow is altered. ${ }^{15}$ The biological half-life of antipyrine is about 12 hours, and antipyrine can be ingested in a relatively high dose. After oral ingestion, antipyrine is uninformly distributed over the total body water and not only the extracellular water compartment like salicylic acid. ${ }^{15}$ Coolen et $\mathrm{al}^{23}$ furthermore showed that the sensitivity of the HPLC to separate antipyrine and its phenolic derivatives increased by a factor 100 to 1,000 when MS was used as a detector instead of the commonly used ultraviolet (UV)-spectrophotometer. The recently developed method ${ }^{19}$ used in this study is highly selective in measuring the expected low concentrations of antipyrine and its phenolic derivatives in plasma. Therefore, this method should have been sensitive and selective to measure the potentially small changes in plasma concentrations of antipyrine and its free radical reaction products in exercising older humans.

Interestingly, Coolen ${ }^{24}$ observed no significant increase in the free radical products of antipyrine in young adults after exercise. Those 19 young male adults $(23 \pm 1$ years; $22 \pm 1$ $\mathrm{kg} \cdot \mathrm{m}^{-2}$ ) cycled for 2 hours at the same relative submaximal intensity $\left(50 \% \mathrm{~W}_{\max } ; 154 \pm 7 \mathrm{~W}\right)$ as the elderly subjects in this study. The exercise-induced oxidative stress of the young adults was compared with a 2-hour resting condition. No significant changes in the ratios of $\mathrm{p}-\mathrm{APOH}$ and $\mathrm{o}-\mathrm{APOH}$ to antipyrine could be observed. Additionally, no significant difference in the level of MDA before and after 2 hours of exercise was observed. Coolen ${ }^{24}$ proposed that the training status of the subjects $\left(\mathrm{VO}_{2 \max }: 4.1 \pm 0.1 \mathrm{~L} \cdot \mathrm{min}^{-1}\right)$ was too high to observe an effect on exercise-induced oxidative stress at such a moderate intensity, which is similar to a previous finding. ${ }^{8}$ It has to be mentioned, however, that food intake was not 
measured in both younger and older adults. Therefore, we cannot exclude that part of the differences found can be attributed to differences in food intake. In the present study, the level of MDA significantly increased during and after exercise (Fig 2). Although the older subjects in this study were relatively unfit (Table 1), which makes comparison of the data with young adults rather difficult, it could be argued that the increased levels of MDA and free radical reaction products of antipyrine might indicate a clear exercise-induced oxidative stress. In Fig 1, it is clearly shown that exercise results in an increase in the ratio of the hydroxylated metabolites to the plasma antipyrine concentration in almost every subject.

It could be argued, however, that subjects performed the maximal exercise test and the submaximal exercise trial on 1 day, which could have influenced the measured exercise-induced oxidative stress. To minimize the effect of the maximal exercise test, the time between the 2 cycling test was at least 2 hours. Recently, Leaf et $\mathrm{al}^{25}$ observed in 7 healthy men and women that the expired ethane and pentane levels (markers of lipid peroxidation) were already declining 5 minutes after performing a maximal exercise test. This suggests that the residual effect of the time frame used on the measured oxidative stress is probably negligible. Additionally, all the subjects were able to perform the 45-minute cycling test without physical complaints.

It has to be mentioned, however, that the lack of a resting control group is a limitation of this study. It could be argued that the increase in $\mathrm{p}-\mathrm{APOH}$ and $\mathrm{o}-\mathrm{APOH}$ was due to the fact that under normal resting conditions $2 \%$ to $5 \%$ of the total electron flux leaks to form primary short-lived ROS, such as superoxide, hydrogen peroxide and $\mathrm{OH}^{-} \cdot{ }^{26}$ This explanation seems unlikely, because an increase in the ratios of $\mathrm{p}-\mathrm{APOH}$ and o-APOH to native antipyrine was observed between the pre- and postexercise condition. In addition, the increase in these ratios was highly significant $(P<.0001)$. Furthermore, the plasma MDA levels were increased almost $70 \%$ after exercise (Fig 2). Although the TBA assay lacks specificity when applied to human plasma, ${ }^{2}$ it seems that in older adults, submaximal exercise results in an increased oxidative stress.

In view of the age-related increase in the susceptibility to oxidative stress, one might speculate if untrained older adults would benefit from following an exercise training program. Leeuwenburgh et $\mathrm{al}^{27}$ showed that 10 weeks endurance training increased GSH peroxidase and superoxide dismutase content in the deep vastus lateralis muscle of young rats, but had no effect on antioxidant enzyme content in old rats. They suggested that aged skeletal muscle had a limited capacity to further increase its antioxidant potential. So far, no studies have been conducted in healthy older adults in which oxidative stress was measured before and after a training period. It would be informative to know whether training is effective in the induction of the antioxidant system, and whether the elderly are able to cope with an increase in oxidative stress following a training program.

In conclusion, the present study demonstrated that in older adults, oxidative stress occurred during a single bout of submaximal endurance exercise as measured with free radical reaction products of antipyrine.

\section{ACKNOWLEDGMENT}

The authors wish to thank Joan Senden for placement of the Teflon catheters and assistance during the MDA analyses. We would also like to thank Joost van Dongen from the Laboratory for Macromolecular and Organic Chemistry for assistance during the HPLC-MS experiments.

\section{REFERENCES}

1. Sen CK: Oxidants and antioxidants in exercise. J Appl Physiol 79:675-86, 1995

2. Halliwell B, Gutteridge JMC: Free Radicals in Biology and Medicine (ed 2). Oxford, UK, Claredon, 1989

3. Bejma J, Ji LL: Aging and acute exercise enhance free radical generation in rat skeletal muscle. J Appl Physiol 87:465-470, 1999

4. Khalil A, Wagner JR, Lacombe G, et al: Increased susceptibility of low-density lipoprotein (LDL) to oxidation by gamma-radiolysis with age. FEBS Lett 392:45-48, 1996

5. Mecocci P, Fano G, Fulle S, et al: Age-dependent increases in oxidative damage to DNA, lipids, and proteins in human skeletal muscle. Free Radic Biol Med 26:303-308, 1999

6. Hageman JJ, Bast A, Vermeulen NP: Monitoring of oxidative free radical damage in vivo: Analytical aspects. Chem Biol Interact 82:243293, 1992

7. Lovlin R, Cottle W, Pyke I, et al: Are indices of free radical damage related to exercise intensity. Eur J Appl Physiol 56:313-316, 1987

8. Vasankari T, Kujala U, Heinonen O, et al: Measurement of serum lipid peroxidation during exercise using three different methods: Diene conjugation, thiobarbituric acid reactive material and fluorescent chromolipids. Clin Chim Acta 234:63-69, 1995

9. Alessio HM, Goldfarb AH: Lipid peroxidation and scavenger enzymes during exercise: Adaptive response to training. J Appl Physiol 64:1333-1336, 1988

10. Coudray C, Talla M, Martin S, et al: High-performance liquid chromatography-electrochemical determination of salicylate hydroxylation products as an in vivo marker of oxidative stress. Anal Biochem 227:101-111, 1995

11. Tabatabaei AR, Abbott FS: LC/MS analysis of hydroxylation products of salicylate as an indicator of in vivo oxidative stress. Free Radic Biol Med 26:1054-1058, 1999

12. Kaur H, Halliwell B: Detection of hydroxyl radicals by aromatic hydroxylation. Methods Enzymol 233:67-82, 1994

13. O'Neill CA, Stebbins CL, Bonigut S, et al: Production of hydroxyl radicals in contracting skeletal muscle of cats. J Appl Physiol 81:1197-1206, 1996

14. Coolen SA, Huf FA, Reijenga JC: Determination of free radical reaction products and metabolites of salicylic acid using capillary electrophoresis and micellar electrokinetic chromatography. J Chromatogr B 717:119-124, 1998

15. Hartleb M: Drugs and the liver. Part II. The role of the antipyrine test in drug metabolism studies. Biopharm Drug Dispos 12:559-570, 1991

16. Forni LG, Mora-Arellano VO, Packer JE, et al: Aminopyrine and antipyrine free radical-cations: Pulse radiolysis studies of oneelectron transfer reactions. J Chem Soc Perkin Trans 2:1579-1584, 1988

17. Coolen SAJ, Everaerts FM, Huf FA: Characterization of ${ }^{60} \mathrm{Co}$ $\gamma$-radiation induced radical products of antipyrine by means of highperformance liquid chromatography, mass spectrometry, capillary zone electrophoresis, micellar electrokinetic capillary chromatography and 
nuclear magnetic resonance spectrometry. J Chromatogr A 788:95-103, 1997

18. Meijer EP, Westerterp KR, Verstappen FT: Effect of exercise training on total daily physical activity in elderly humans. Eur J Appl Physiol 80:16-21, 1999

19. Coolen SAJ, Van Lieshout M, Reijenga JC, et al: Determination of phenolic derivatives of antipyrine in plasma with HPLC-Tandem MS using ESI and Turbo ionspray as interfaces. J Microcolumn Sep 11:701-707, 1999

20. McCabe DR, Maher TJ, Acworth IA: Improved method for the estimation of hydroxyl free radical levels in vivo based on liquid chromatography with elecrtochemical detection. J Chromatogr B 691: 23-32, 1997

21. Leaf DA, Kleinman MT, Hamilton M, et al: The exerciseinduced oxidative stress paradox: The effects of physical exercise training. Am J Med Sci 317:295-300, 1999

22. Meydani M, Evans WJ, Handelman G, et al: Protective effect of vitamin $\mathrm{E}$ on exercise-induced oxidative damage in young and older adults. Am J Physiol 264:R992-998, 1993
23. Coolen SAJ, Ligor T, Van Lieshout M, et al: Determination of phenolic derivatives of antipyrine in plasma with solid-phase extraction and high-performance liquid chromatography-atmospheric-pressure chemical ionization mass spectrometry. J Chromatogr B 732:103-113, 1999

24. Coolen SAJ: Antipyrine hydroxylates as indicators for oxidative damage. PhD thesis, Eindhoven University of Technology, Eindhoven, the Netherlands, 2000

25. Leaf DA, Kleinman MT, Hamilton M, et al: The effect of exercise intensity on lipid peroxidation. Med Sci Sports Exerc 29:10361039, 1997

26. Boveris A, Chance B: The mitochondrial generation of hydrogen peroxide. General properties and effect of hyperbaric oxygen. Biochem J 134:707-716, 1973

27. Leeuwenburgh C, Fiebig R, Chandwaney R, et al: Aging and exercise training in skeletal muscle: Responses of glutathione and antioxidant enzyme systems. Am J Physiol 267:R439-445, 1994 